\title{
List of maps and figures
}

\section{Maps}

1 Map of Algeria xviii

2 Map of the region of Kabylia xix

3 Map of the FLN-ALN wilayat during the War of Independence $\mathrm{xx}$

4 Map of Algiers $\quad$ xxi

\section{Figures}

1 French soldiers patrol homes in the douars (villages) of Kabylia, 1957 (@ Jean-Philippe Charbonnier / Getty Images)

2 The arrest of FLN militant Zohra Drif by the French army, 24 September 1957 (C AFP / Getty Images)

3 Women walking through the Algiers Casbah, 1969

(C) Bruno Barbey / Magnum Photos)

4 On the fifth anniversary of Boumediene's coup, a woman in Oran holds a banner comparing the president with the Emir Abdelkader, the nineteenth-century hero of the Algerian resistance, 19 June 1970 (C Guy Le Querrec / Magnum Photos)

5 Women in Algiers walk past a poster celebrating the independence struggle, 1982 (@) Abbas / Magnum Photos)

6 A couple outside the Riad el Feth shopping precinct, at the foot of Maqam al-Shahid (the Monument to the Martyr) in Algiers, 1999 (C) Raymond Depardon / Magnum Photos) 